\title{
Diet selection by the social vole Microtus socialis (Pallas, 1773) in the Northwest Caspian Lowland
}

\author{
Alexey E. Scopin*, Vita V. Dzhapova, Olga G. Bembeeva, Elena Ch. Ayusheva, \\ Raisa R. Dzhapova \& Boris D. Abaturov
}

\begin{abstract}
The article presents the research results the food selection and preferences of the social vole Microtus socialis in the dry steppes (northern subzone of the deserts) in the Chernye Zemli State Biosphere Reserve (north-western part of the Caspian Lowland). It is the first time when the data on seasonal variability of food composition of social voles in their permanent settlements has been obtained by means of cuticular microhistological feces analysis. The diet of the voles consists of 31 plant species. The basis of the diet is grasses (55-95\%), mainly Poa bulbosa. Forbs are consumed in smaller amounts, but they play an important role in the summer life of the rodent. In spring, the tulip bulbs (Tulipa biebersteiniana) and the terrestrial parts of Chorispora tenella are of greatest importance in the nutrition of the vole. These herbivores do not eat Bassia hyssopifolia, Phlomis pungens, Carduus acanthoides at all. Voles maximize the use of forage diversity in the area of their settlements. The trophic interactions of rodents to certain plant species were evaluated through the preferences of baits containing plant extracts. The social voles consume baits with extracts from different plant species in varying degrees. In general, the consumption of baits containing grass extracts is higher than that of baits containing extracts from most species of forbs. In the group of forbs, the social vole unequivocally prefer baits containing tulip extracts. The baits with other forbs are consumed by two or more times less than those with grass extracts. The social vole gives the least preference to baits with extracts from Senecio vernalis and Tanacetum achilleifolium. Most likely, a high concentration of toxic secondary metabolites is the main reason for voles avoiding certain baits with plant extracts.
\end{abstract}

How to cite this article: Scopin A.E., Dzhapova V.V., Bembeeva O.G., Ayusheva E.Ch., Dzhapova R.R., Abaturov B.D. 2020. Diet selection by the social vole Microtus socialis (Pallas, 1773) in the Northwest Caspian Lowland // Russian J. Theriol. Vol.19. No.2. P.136-148. doi: 10.15298/rusjtheriol.19.2.04.

KEY WORDS: Microtus socialis, food selection, forage composition, arid ecosystems, Caspian Lowland.

AlexeyE.Scopin [scopin@bk.ru],Prof. B.M. Zhitkov Russian Research Institute of Game Management and Fur Farming, 79 Preobrazhenskaya Str., Kirov 610000, Russia; Vita V. Dzhapova [dzhapova@list.ru], Department of Veterinary Science, Kalmyk State University, 11 Pushkina Str., Elista 358000, Kalmyk Republic, Russia; Olga G. Bembeeva [bembeeva_og@mail.ru], Institute for Integrated Studies of Arid Territories of the Kalmyk Republic, 111 Khomutnikova Str., Elista 358005, Kalmyk Republic, Russia; Elena Ch. Ayusheva [ayushevae@mail.ru], Kalmyk State University, Department of Botany, 11 Pushkina Str., Elista 358000, Kalmyk Republic, Russia; Raisa R. Dzapova [djapova04@mail. ru], Department of Botany, Kalmyk State University, 11 Pushkina Str., Elista 358000, Kalmyk Republic, Russia, Kalmyk Republic; Boris D. Abaturov [abaturovbd@mail.ru], A.N. Severtsov Institute of Ecology and Evolution, 33 Leninski Prospekt, Moscow 119071, Russia.

\section{Кормовая избирательность общественной полевки Microtus socialis (Pallas, 1773) на северо-западе Прикаспийской низменности}

\author{
А.Е. Скопин*, В.В. Джапова, О.Г. Бембеева, Е.Ч. Аюшева, \\ P.P. Джапова, Б.Д. Абатуров
}

РЕЗЮМЕ. Представлены материалы по избирательности питания общественной полевки Microtus socialis в сухих степях (северная подзона пустынной зоны) заповедника «Черные земли» (северо-западная часть Прикаспийской низменности). С помощью кутикулярного микрогистологичексого анализа экскрементов впервые получены данные по сезонной изменчивости состава кормов на постоянных поселениях полевок. В рационе общественной полевки зарегистрирован 31 вид растений. Основу рациона составляют злаки (55-95\%), преимущественно Poa bulbosa. Разнотравье потребляется полевкой в меньшем количестве, но оно играет важную роль в летний период. В весенний период

* Corresponding author 
наибольшее значение в питании полевки имеют луковицы Tulipa biebersteiniana и надземные части Chorispora tenella. Совсем не поедаются этими травоядными Bassia hyssopifolia, Phlomis pungens, Carduus acanthoides. Полевки максимально используют корма в районе своих поселений. Трофическое отношение грызунов к определенным видам растений оценивали через избирательность предпочтения приманок, содержащих растительные экстракты. Приманки с разными видами растений общественные полевки потребляют в разной степени. В целом потребление приманок, содержащих экстракты из злаков выше, чем приманок, содержащих экстракты из большинства видов разнотравья. В группе разнотравья общественные полевки отдают явное предпочтение приманкам с экстрактами тюльпана. Приманки с остальными представителями разнотравья потребляются в два и более раза меньшем количестве, чем с экстрактами из злаков. Наименее охотно общественные полевки поедают приманки с экстрактами Senecio vernalis и Tanacetum achilleifolium. Скорее всего, высокая концентрация токсичных вторичных метаболитов служит основной причиной избегания в потреблении полевками приманок с определенными растительными экстрактами.

КЛЮЧЕВЫЕ СЛОВА: Microtus socialis, избирательность питания, состав кормов, аридные экосистемы, Прикаспийская низменность.

\section{Introduction}

Steppe ecosystems cannot exist without consumers. Herbivores are one of the key elements in the functioning of the grassland biomes (Abaturov, 1984; Scholes \& Walker, 1993; Owen-Smith, 2005; Gordon, 2006; Stapp et al., 2008; Archibald et al., 2020). In grass communities, various species of small rodents have a huge impact on the removal of phytomass and its involvement in the biological cycles (Zlotin \& Khodasheva, 1974; Zaichenko, 1996; Kaufman \& Kaufman, 1997; Byrom et al., 2015).

The social vole (Microtus socialis Pallas, 1773) is a successful evolutionary model of trophic adaptation of herbivorous mammals in the steppe, mountain and arid territories, since it plays an important ecosystem role in these biomes, and it can also act as a pest in agrosystems (Voronov, 1935a, b; Ivanenko, 1940; Vereshchagin, 1946; Berishvili, 1968; Kokhiya, 1968; Kasatkin 2002; Bykov et al., 2008, 2011). The social vole is common within some local territories in the south of Eastern Europe, the Caucasus, the Middle East and Central Asia (Pardinas et al., 2017). However, its distribution is mosaic, sometimes with wide gaps in the range, which is associated with periods of deep depressions in the abundance of this species in the Holocene, caused by extensive xerophytization of landscapes (Gromov \& Polyakov, 1977). After deep population depressions, many territories are no longer re-inhabited by this vole. The fragmentation of a large range in the Pleistocene-Holocene is associated with the appearance of different morphological forms of voles in the social group, many of which are now recognized as separate species (Kryštufek et al., 2009, 2012; Pardinas et al., 2017).

The social vole leads a family-colonial lifestyle. The colonies have a clear boundary in nature and their distribution is largely related to the biotope features - the vegetation composition and the nature of the soil, which is important for constructing a complex burrow system with a large number of exits, sometimes forming large underground settlements (Argiropulo, 1935; Voronov, 1935a, b; Naumov, 1948; Kasatkin et al., 1998; Khalilaria \& Çolak, 2013; Bukhareva \& Bykov, 2014).

The study of social voles is of particular interest in arid ecosystems, where their populations are most sensitive to many environmental factors. A decrease in the number of voles in areas with an intensification of the dry climate and overgrazing has been recorded (Neronov et al., 1997). The social vole is a long-term monitored species of small herbivorous mammals in the southeast of Kalmykia that is located in the zone of the dry steppes and semi-deserts (Mironov, 1945; Kasatkin et al., 1998; Shilova \& Kasatkin, 2000; Bykov et al., 2011; Bukreeva \& Lidzhi-Garyaeva, 2018). In recent years, there has been a significant increase in the number and distribution of the social vole in the Caspian Lowland (Kasatkin et al., 1998; Bukreeva \& Lidzhi-Garyaeva, 2018). The share of these voles on average varies from 16 to $47 \%$ of all other small rodents in the community, but in 2016 this indicator for the Chernye Zemli Reserve reached 63\% (Bukreeva \& Lidzhi-Garyaeva, 2018). This gives us a good opportunity to consider aspects of the relationship between voles and their natural forages within this territory.

The voles consume and destruct a large volume of phytomass during periods of mass breeding (Khodasheva, 1960). An uneven distribution of the voles by habitats in the dry steppe is associated with a change in the composition and quality of the feed and soil features, which ultimately largely causes fluctuations in the abundance of the rodents. At the same time, many ecological aspects of nutrition and forage selection of the social vole in nature are quite poorly studied, although the assessment of trophic adaptations with decreased diversity of food plants and frequent feed shortages is extremely important for understanding how these rodents survive in severe arid conditions. To date, there has been only sporadic information on the digestion in the social voles (Khashaeva, 1993; Abaturov \& Khashaeva, 1995). There are few studies about different aspects of nutrition of this rodent in nature (Rodionov, 1924; Voronov, 1935a, b; Formozov \& Kiris, 1937; Kokhiya, 1968; Polishchuk, 
1985; Larionov et al., 2011; Magomedov, 2017). One of the main features of the feeding of the social vole is that when the quality of the forage deteriorates, the digestibility of the ingested food decreases sharply (Abaturov \& Khashaeva, 1995). This makes the vole select plants on the pastures with particular thoroughness.

The aim of our study is to determine the diet selection of the social vole on the basis of the analysis of the composition and seasonal dynamics of the consumed plants and to compare these results with preferences to certain baits with unequal concentration of plant toxic compounds from the point of view of safe use of food plant natural resources in ecosystems.

\section{Material and methods}

The fieldwork and experiments were conducted in the Caspian Lowland on the territory of Chernye Zemli State Biosphere Reserve (the Republic of Kalmykia, Russia) in 2018. The studied colonies of social voles were located in the conservation zone of this reserve (coordinates:

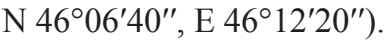

The Caspian Lowland is a plain with rare mild elevations, hollows and flat-bottomed depressions. The sand massifs of varying degrees of vegetation are often found here. The climate is sharp continentality: summer is dry and hot, winter has little snow, but sometimes has severe frosts (Doskach, 1979).

The territory of the Chernye Zemli Reserve has a fairly large plant species diversity (291 species), which is determined by the abundance of different landscapes and a sharp change of vegetation according to season. This is most clearly manifested in the ephemeral appearance of many species in spring and the depletion of plant diversity in winter and summer. In the last century, a large part of this territory was degraded due to overgrazing and desertification. Now one can observe restoration of the vegetation cover. A more detailed description of the natural conditions and vegetation in the reserve has already been described in publications (Trofimov, 1995; Neronov, 1999).

The territory of the experimental site belongs to the East Chernozeml'ski region, where Agropyron-Kochia, grass-Artemisia and Stipa-grass communities on sandy and sandy-brown loam soils prevail. The zonal vegetation is represented by Poa bulbosa-Artemisia lerchiana communities sometimes in combination with vegetation of different types of saltlands (Anabasis, Atriplex, Salsola, etc.) (Tsatsenkin et al., 1957). We distinguished three plant communities (Poa bulbosa-Stipa sareptana, Poa bulbosa, Carex stenophylla-Poa bulbosa) within the experimental site. The composition of plant species in different communities varies greatly during a year. However, the plant diversity does not usually exceed one or two dozen species.

The geobotanical studies near the social vole colonies were carried out in spring (middle April), summer (late May) and autumn (middle October) in 2018. The vegetation has been described on a standard area of at least $100 \mathrm{~m}^{2}$ in size. Aboveground plant mass was recorded on mowing sites $(2.5 \mathrm{~m} \times 1 \mathrm{~m})$. This scheme of geobotanical work had been used in the Chernye Zemli Reserve since the middle of the last century (Chizhikov, 1954). The average productivity of the mowing plots on the experimental site was determined taking into account the fraction of the aboveground mass of each plant community that is part of the overall investigated plant complex (Ponyatovskaya, 1964; Bykov, 1978). Thirty six plots were randomly distributed near the investigated vole colonies (12 in each month of observation). At each plot, the total biomass of vegetation and individual plant species was determined. The biomass of individual plant species expressed as fractions of $100 \%$ is shown in Table 1.

The microhistological analysis of feces was used to determine the species composition of food plants (Stewart, 1967; Phillipson et al., 1983; Larionov et al., 2011; Okulova et al., 2015). The fresh feces of the social vole were collected in the five colonies at the hole entries during a few days in April, May, and October. Since family groups adhere to the same burrows for several months (Kasatkin et al., 1998), it is highly probable that samples collected over the course of a year were from the same family groups.

The atlas of photographs of the cuticular structure of the plants of the Chernye Zemli Reserve was prepared to identify the botanical fragments from feces (Dzhapova et al., 2019). The ratio of plant species in the diet has been examined under a microscope by the frequency of occurrence of cuticle fragments of each plant species in the feces sample. We prepared 318 samples on the coverslips in April, 671 - in May and 495 - in October. Most of the unidentified plant fragments were represented by the underground parts, which are difficult to diagnose to the species level.

To assess preferences in the selection of different types of food plants by voles, two selectivity indices were calculated: the Savage-Shorygin selectivity index (SSS index) (Shorygin, 1939) and classic Ivlev's electivity index (IE index) (Ivlev, 1946). The SSS index is calculated as the ratio of the share of the plant species in the diet (\%) to its share in the aboveground plant biomass (\%). The higher the value of the selectivity index is the greater preference the social vole gives to this plant. This index is often used to assess the food selectivity of herbivores in the steppe (Kazmin et al., 2013; Abaturov et al., 2018, 2019); it allows us to compare our results with the data for other mammalian species. The IE index (IE $=r-p / r+p$, where $r$ - proportion in the diet, $p$ proportion in the environment) is more representative and widely used but limited on the scale of use: from -1 (negative selection - avoidance) to +1 (positive selection - preference). Food selectivity indices were not calculated in cases when the plant species was noted only in the diet but was not present in the pasture. This means that rodents also consumed the plants from forage supply in burrows, which we did not assess.

The trophic preference by voles of certain food plants in a comparative aspect was assessed through the analysis 


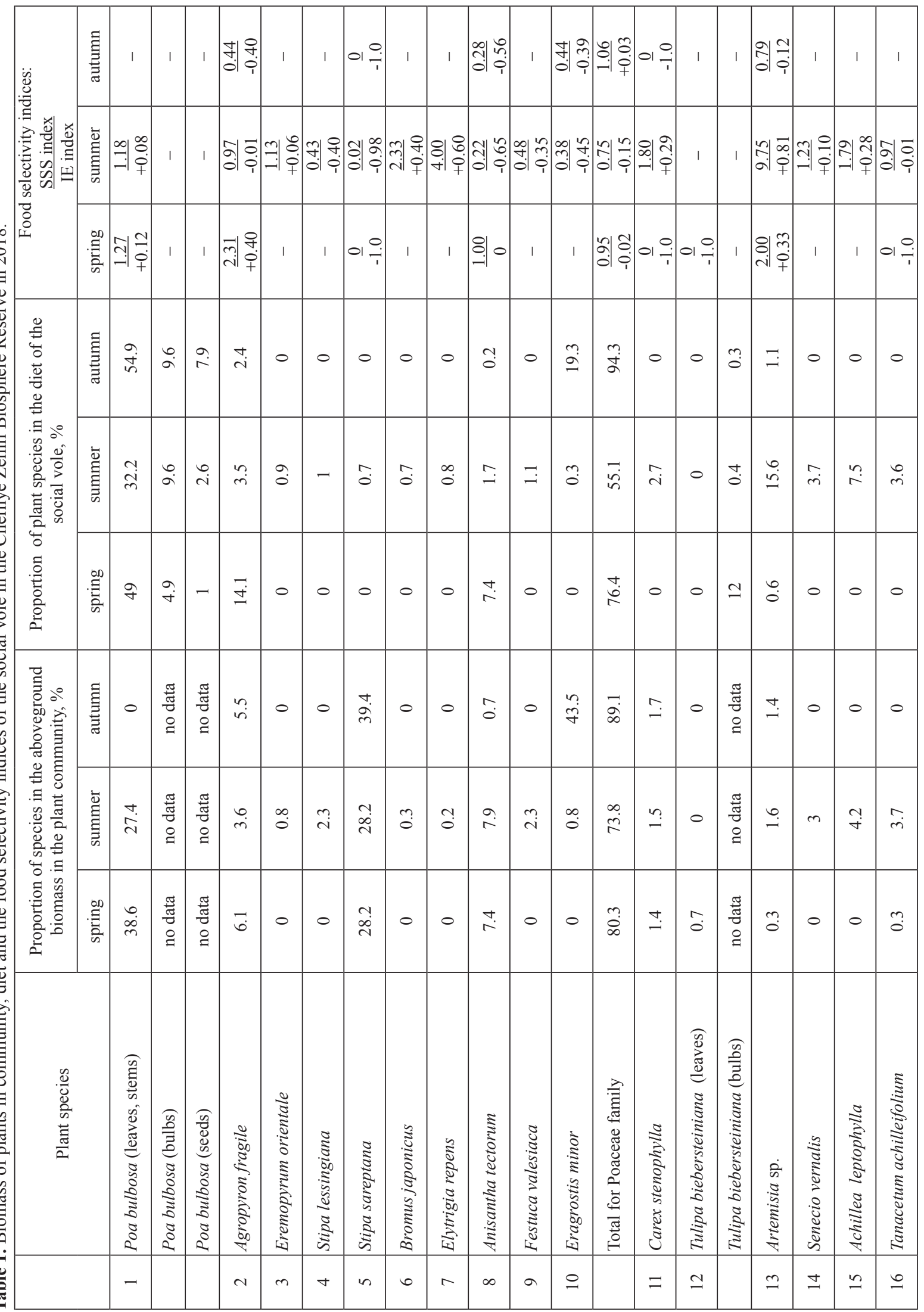




\begin{tabular}{|c|c|c|c|c|c|c|c|c|c|c|c|c|c|c|c|c|c|c|c|c|c|}
\hline & 童 & 1 1 & त̂t: & ầ & 1 & 1 & 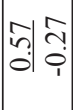 & 1 & & |̇: & :ִ & 1 & I & I & 1 & -10 & 1 & 1 & 1 & & ถึ? \\
\hline 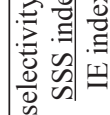 & & & 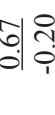 & & & & tat & 쵱 & 1 & 1 & $\begin{array}{l}a \\
\dot{d}\end{array}$ & & 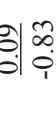 & \begin{tabular}{l}
7 \\
\hdashline \\
0
\end{tabular} & 1 & 10 & 01 & & ס. & & \\
\hline & 訔 & & 1 & 1 & 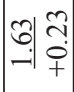 & 1 & 1 & $01 \stackrel{0}{-1}$ & 1 & 1 & 1 & 资 & 1 & $01 \stackrel{0}{-1}$ & 1 & I & 1 & 1 & 1 & & 위 \\
\hline 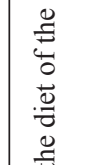 & 言 & o & $\tilde{o}$ & $\stackrel{+}{\circ}$ & 0 & 0 & 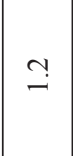 & 0 & 0 & 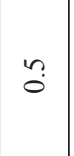 & $\stackrel{m}{0}$ & 0 & בี & $\stackrel{\sim}{0}$ & 0 & 3 & 0 & 0 & 0 & - & $n$ \\
\hline 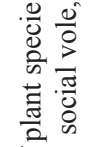 & 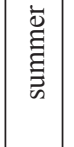 & $\stackrel{\infty}{\infty}$ & $\stackrel{\infty}{\infty}$ & 3 & $\sim$ & $\exists$ & $\stackrel{\circ}{-}$ & $\stackrel{3}{3}$ & $\stackrel{\nabla}{\circ}$ & $\stackrel{\circ}{\circ}$ & $\overline{0}$ & 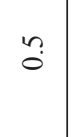 & $\overrightarrow{0}$ & กั & $\overline{0}$ & 0 & 0 & 0 & 0 & $\stackrel{n}{i}$ & $\dot{f}$ \\
\hline 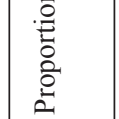 & 点 & & 0 & 0 & $\stackrel{+}{\subseteq}$ & 0 & 0 & 0 & 0 & 0 & 0 & $\stackrel{\circ}{\circ}$ & 0 & 0 & 0 & 0 & 0 & 0 & 0 & 。 & $\pi$ \\
\hline
\end{tabular}

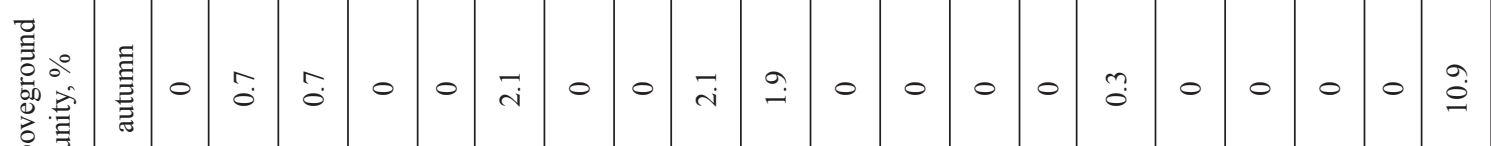
要

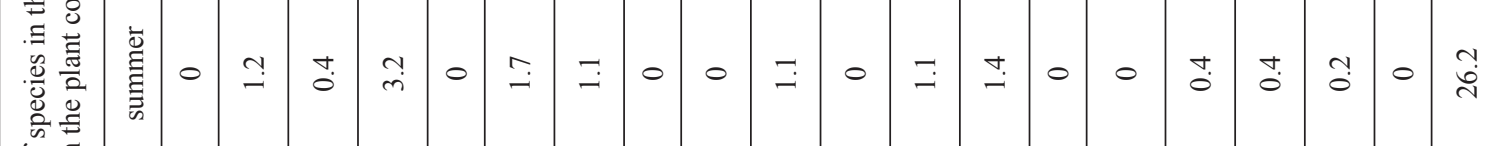
范.

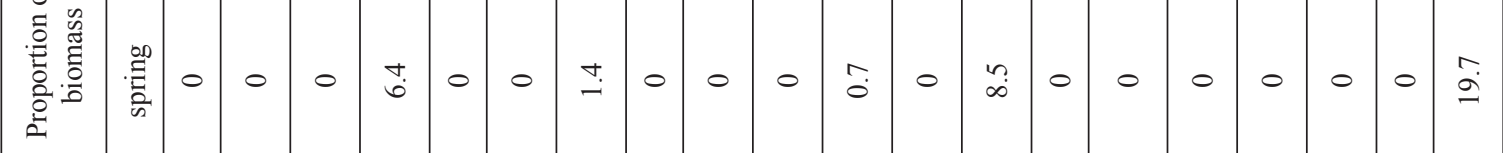

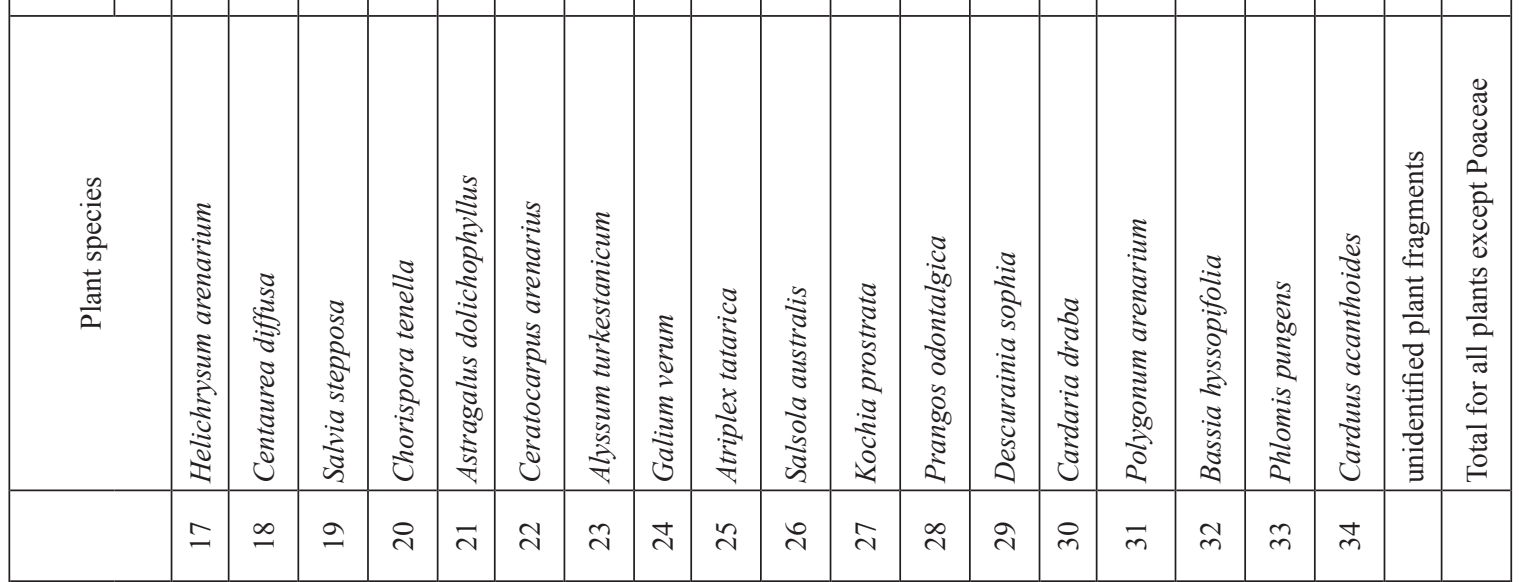


of consumption of grain baits containing water extracts from these plants (Scopin, 2000, 2003). The degree of use of the baits was considered as an indicator of attractiveness or repellency of certain plants to the rodent. The aboveground parts of different plants were collected at the social vole settlements in April and October. The plant samples were dried at room temperature. The extracts were prepared at a concentration of $1 \mathrm{~g}$ of an air-dry powder sample of the analyzed plant species per $10 \mathrm{ml}$ of distilled water. The whole refined oat grains were used as bait, which were soaked in extracts for at least 3 hours. The oat grains soaked in distilled water were used as a control bait. Equal weights of baits (20-30 seeds - about $0.5-0.7 \mathrm{~g}$ each) were laid out in the cells of the plates of the enzyme-immunoassay. Each vole was offered a choice of 20-24 baits with different extracts at the same time on one plate. The plates were left for 10-12 hours in cages placed in the steppe. The experimental plates with baits were usually put in the cages in the evening, and taken out in the morning. Voles consumed at least $1 / 3$ of the total mass of proposed baits during this time. The social voles have been caught in advance in live traps and kept in the cages singly. After the experiment, the voles were offered ad libitum the usual forage grain and grass. The drinking water was in the cages all the time.

The selectivity of baits with different plant extracts was evaluated by two indicators: 1 . The percentage of the baits consumed in ratio to the initial amount of baits $(\%) ; 2$. The percentage of the baits consumed in ratio to control bait. The consumption by voles of control oat seeds saturated with water was taken as $100 \%$. The lower the indicator is, the less attractive the bait is for the voles. The indicator higher than the control one characterizes a high degree of attractiveness of the bait with these plant extracts. These two indicators are usually closely related and strongly correlated. The second indicator (calculation of the ratio to the use of bait control) must be used to minimize the error in the level of forage consumption by different individual voles. Since different individual voles eat different amount of seeds, it is necessary to control the consumption of the experimental baits in ratio to the control ones. The statistical significance of the bait consumption by season has been determined by the t-test.

\section{Results}

\section{Vegetation}

The vegetation of the experimental site of the dry steppe is represented by a complex of three components: Poa bulbosa-Stipa sareptana community (share in the investigated grassland - 50\%), Poa bulbosa community (40\%) and Carex stenophylla-Poa bulbosa community $(10 \%)$. The first two plant communities are confined to the brown semi-desert soils of sandy-loam granulometric composition, the third is found on the meadow-brown soils of small surface depressions of the relief. It should be noted that Eragrostis minor dominated in the biomass of all communities in autumn; therefore, this species accounts for a significant proportion of the autumn composition of the phytomass. Poa bulbosa was present in the form of bulbs on the surface of the soil in autumn. The total aboveground phytomass of the plant community by season: spring-summer-autumn amounted to $25.0-32.8-16.0 \mathrm{~g} / \mathrm{m}^{2}$ respectively for Poa bulbosa community; 33.6-62.2-40.2 g/ $/ \mathrm{m}^{2}$ for Poa bulbosa-Stipa sareptana community; $26.0-31.5-24.3 \mathrm{~g} / \mathrm{m}^{2}$ for Carex stenophylla-Poabulbosa community. The plant biomass, expressed as a percentage for each species, is presented in Table 1.

The average aboveground mass of vegetation in the surveyed area was $29.5 \pm 0.5 \mathrm{~g} / \mathrm{m}^{2}$ in spring, $47.4 \pm$ $1.1 \mathrm{~g} / \mathrm{m}^{2}$ in summer, and $28.9 \pm 0.5 \mathrm{~g} / \mathrm{m}^{2}$ in autumn. The species composition of all plant communities is represented by 34 species of plants. The biomass on randomly selected plots was composed of 29 species. Cardaria draba, Galium verum, Helichrysum arenarium, Astragalus dolichophyllus were not found at the randomly selected plots.

Different grasses dominate in the biomass (70-90\%) near the vole colonies in all snowless months. The rest of the plant biomass consists of forbs. The value of grass biomass is lower in summer what is associated with both burning of vegetation and its consumption by herbivores. The proportion of grass biomass increases again due to regrowth in autumn. In the group of grasses, ten plant species were registered, but only five species (Poa bulbosa, Agropyron fragile, Stipa sareptana, Anisanta tectorum), and additionally in the autumn - Eragrostis minor make up the basis of the biomass. The biomass of other plants in the vole colonies is mainly forbs with small indices of coverage and abundance. The highest biomass is reached by Chorispora tenella, Alyssum turkestanicum, Descurainia sophia in spring, Achillea leptophylla, Tanacetum achillefolium, Chorispora tenella in summer, and Ceratocarpus arenarius, Atriplex tatrica, Salsola australis in autumn.

\section{Forage composition and diet selection of} the social vole

Thirty one species of plants were registered in the diet of the vole. The spring diet includes only seven plant species. The most diverse diet consists of 29 species of plants in summer and the scarcest diet is in autumn (6 species). The percentage ratio of grasses and forbs was 80.3 / 19.7 in the spring, 73.8 / 26.2 in the summer; $89.1 / 10.9$ in the autumn. The grasses prevail in the aboveground biomass of plants in the experimental site in all seasons.

The diet of voles consists mainly of grasses (Poaceae) (from $55 \%$ in summer to $95 \%$ in autumn) (Tab. 1) because of their predominance in the surrounding plant communities. The proportion of grasses in the diet is less in summer. This is most likely due to the fact that the forage base around the rodent settlements is already severely damaged and the grasses are burned out. Dried grasses are no longer valuable and unattractive for the 
voles. All species of grasses that grow on the territory of the vole colonies are represented in its diet to one degree or another. Only three species of grasses were present in the nutrition of voles in the spring despite the large abundance of different plant species. In the summer, ten species were registered in the diet, and diversity of grasses in the diet decreases again to four species in autumn.

The basis of the diet of the social vole (about $50 \%$ ) is Poa bulbosa. The bulbs and seeds of this plant also have a great importance in the vole nutrition in the summer-autumn period. In many cases, the frequency of occurrence in the diet of a particular species of grasses depends on its abundance in the plant community. However, there are some exceptions. The genus Stipa is abundant but practically not eaten. The frequency of occurrence of grasses in the diet also depends on the seasonal change of vegetation. The share of Agropyron and Anisantha drops several times from spring to autumn. On the contrary, Eragrostis minor growing in autumn makes up about $20 \%$ of the diet in this season.

The number of the consumed species of forbs is three times higher than that of grasses, but they never reach such high biomass in the community, therefore their role in the diet is less significant and especially important in the summer when grasses lose their attractiveness for the social vole.

An important feature of consumption of different forbs by voles is the consumption of this food in summer (May) i.e. during the period of active growth and diversity of different plants. Whereas at the beginning of the vegetative season (April), the social voles consumed only four forbs species, in May there were already 20 species, i.e., almost all species that are found in the community. The number of grass species consumed by voles fell again to ten in autumn.

The bulbs of Tulipa biebersteiniana and the aboveground parts of Chorispora tenella are of the greatest importance in the diet of the social vole in spring. Artemisia species and Achillea leptophylla are consumed in quantities similar to forbs in May. Artemisia and Ceratocarpus arenarius are most consumed by voles in autumn due to predominance of these plants in the ecosystems. In the group of forbs, unlike grasses, there is a clear heterogeneity in the choice of forage plants by the rodents. The highest food selectivity indices were shown for the consumption of species of the genus of Artemisia and Achillea leptophylla of the Asteraceae family in May. The social voles exhibit high selectivity for rare plants and for the plants not found in the community Helichrysum arenarium, Astragalus dolichophyllus, Galium vernum. On the contrary, the widespread Bassia hyssopifolia, Phlomis pungens, Carduus acanthoides are not eaten by the social vole at all.

Considering the selectivity indices, it should be noted that the SSS index is extremely low - it does not exceed 1 in $63 \%$ of the forage plant species eaten by voles, and this index is higher than 2 only for four plant species (Agropyron in spring, Bromus and Elytrigia in summer and Artemisia during the year). This demonstrates a weak degree of food selectivity of the voles in relation to the majority of forage plants. It is also confirmed by the IE index. IE index is always positive for only $20 \%$ of plant species, but still mainly slightly positive. A highly positive IE index (high electivity) is recorded only for Bromus, Elytrigia, and Artemisia in summer. The IE index is characterized by both positive and negative values in $16.7 \%$ of plant species in accordance with the season. However, the vast majority of plant species in the pasture $(63.3 \%)$ are species for which the IE index is negative. These are forage plants not preferred in the diet of the social vole. High consumption of these plants is associated with their predominance on the pasture. Thus, plant species with negative IE index values can be considered as non-select forage items.

If we consider the group of grasses as a whole, the SSS index is close to 1, and the IE index is about zero. The grasses can be interpreted as a group representing the main food of voles, which they do not demonstrate obvious preference to, but also do not avoid. As for forbs, in different seasons the selectivity indices vary slightly: the SSS index is on average higher than 1 in spring and summer, as well as the IE index is positive in spring and summer. This can be interpreted as voles' preference to consume some species of forbs (primarily Artemisia). This is largely due to a high diversity of forage vegetation near the colonies during these seasons. In summer, 26 plant species were recorded in the vole settlements, with 11 and 12 in spring and autumn, respectively.

Preferences of the baits by the social vole

The selective feeding of voles is a behavioral mechanism for choosing the most attractive and safe food. The forages that have toxicity and contain compounds with an unpalatable taste and smell are rejected by an animal. The degree of attractiveness of plant extracts was evaluated by the amount of bait consumed by the rodent. The social voles use baits with different types of extracts in varying degrees. There are no baits with plant extracts which would not be eaten by the social vole, which again demonstrates their high trophic plasticity and the ability to use a wide range of feeds. However, the variability in the choice of certain food by individual rodents is significant.

In general, the consumption of baits containing extracts from Poaceae is higher than that of baits containing extracts from forbs (Tab. 2). For certain vole individuals, this indicator is even higher than the control one. However, in the group of grasses, these values differ. The consumption of baits with Stipa extracts is even higher than with Poa bulbosa extracts. In the forbs group, the social voles have a clear preference for baits with Tulipa biebersteiniana extracts. The baits with extracts from other forbs species are consumed two or more times less than those with grass extracts. Consumption of baits with extracts from forbs is always lower than the consumption of control baits. The social voles eat the least willingly bait with extracts obtained from Senecio vernalis and Tanacetum achilleifolium (Tab. 2). A lot of 
Table 2. Selectivity of the baits with steppe plant extracts by the social vole (Microtus socialis). $\mathrm{M} \pm \mathrm{m}-$ mean and standard error values, Min-Max - the minimum and maximum values, $n$ - number of individuals of the voles that were used in the experiment, * - statistically significant at $p<0.05$.

\begin{tabular}{|c|c|c|c|c|c|}
\hline \multicolumn{2}{|c|}{ Plant species } & \multicolumn{2}{|c|}{$\begin{array}{l}\text { Bait consumption (\%) of initially } \\
\text { given feed to the vole }\end{array}$} & \multicolumn{2}{|c|}{$\begin{array}{l}\text { Bait consumption (\%) in comparison } \\
\text { with eaten control baits by the vole }\end{array}$} \\
\hline & & Spring & Autumn & Spring & Autumn \\
\hline \multirow{3}{*}{ Poa bulbosa } & $\mathrm{M} \pm \mathrm{m}$ & $34.3 \pm 11.8$ & & $46.9 \pm 17.5$ & \\
\hline & Min-Max & $0-90$ & & $10.0-105.9$ & \\
\hline & $n$ & 7 & & 5 & \\
\hline \multirow{3}{*}{ Stipa lessingiana } & $\mathrm{M} \pm \mathrm{m}$ & $68.6 \pm 8.5$ & & $86.9 \pm 5.3$ & \\
\hline & Min-Max & $15-100$ & & $60-109$ & \\
\hline & $n$ & 11 & & 10 & \\
\hline \multirow{3}{*}{ Stipa sareptana } & $\mathrm{M} \pm \mathrm{m}$ & $47.1 \pm 11.4$ & & $54.8 \pm 15.3$ & \\
\hline & Min-Max & $20-90$ & & $21-105.9$ & \\
\hline & $n$ & 7 & & 5 & \\
\hline \multirow{3}{*}{ Tulipa biebersteiniana } & $\mathrm{M} \pm \mathrm{m}$ & $62.9 \pm 10.3$ & & $72.5 \pm 12.8$ & \\
\hline & Min-Max & $20-100$ & & $28.6-100$ & \\
\hline & $n$ & 7 & & 5 & \\
\hline \multirow{4}{*}{ Artemisia austriaca } & $\mathrm{M} \pm \mathrm{m}$ & $19.1 \pm 5.7$ & $27.7 \pm 7.4$ & $34.7 \pm 11.7$ & $41.2 \pm 11.0$ \\
\hline & Min-Max & $0-50$ & $0-100$ & $0-11.1$ & $0-118.2$ \\
\hline & $n$ & 11 & 15 & 10 & 14 \\
\hline & t-test & \multicolumn{2}{|c|}{$\mathrm{t}=-0.40$} & \multicolumn{2}{|c|}{$\mathrm{t}=-0.86$} \\
\hline \multirow{4}{*}{ Artemisia lercheana } & $\mathrm{M} \pm \mathrm{m}$ & $15.1 \pm 7.1$ & $19.0 \pm 9.3$ & $22.3 \pm 13.7$ & $27.6 \pm 14.6$ \\
\hline & Min-Max & $0-41$ & $0-50$ & $0-61.5$ & $0-55.5$ \\
\hline & $n$ & 7 & 5 & 4 & 4 \\
\hline & t-test & \multicolumn{2}{|c|}{$t=-0.27$} & \multicolumn{2}{|c|}{$\mathrm{t}=-0.34$} \\
\hline \multirow{4}{*}{ Artemisia arenaria } & $\mathrm{M} \pm \mathrm{m}$ & $16.8 \pm 5.5$ & $29.4 \pm 6.2$ & $24.7 \pm 8.0$ & $42.3 \pm 8.4$ \\
\hline & Min-Max & $0-55$ & $0-70$ & $0-72.7$ & $0-91.7$ \\
\hline & $n$ & 11 & 16 & 10 & 14 \\
\hline & t-test & \multicolumn{2}{|c|}{$\mathrm{t}=-1.464$} & \multicolumn{2}{|c|}{$t=-1.43$} \\
\hline \multirow{4}{*}{ Artemisia pauciflora } & $\mathrm{M} \pm \mathrm{m}$ & $11.4 \pm 5.1$ & $38.4 \pm 7.2$ & $17.2 \pm 7.4$ & $58.8 \pm 11.1$ \\
\hline & Min-Max & $0-35$ & $0-95$ & $0-41.2$ & $0-146.2$ \\
\hline & $n$ & 7 & 16 & 5 & 14 \\
\hline & t-test & \multicolumn{2}{|c|}{$\mathrm{t}=-2.16^{*}$} & & \\
\hline & $\mathrm{M} \pm \mathrm{m}$ & $10.0 \pm 3.5$ & & $11.0 \pm 5.5$ & \\
\hline Senecio vernalis & Min-Max & $0-25$ & & $0-29.4$ & \\
\hline & $n$ & 5 & & 5 & \\
\hline & $\mathrm{M} \pm \mathrm{m}$ & $5.9 \pm 2.4$ & $48.6 \pm 13.7$ & $10.1 \pm 5.3$ & $42.5 \pm 16.8$ \\
\hline & Min-Max & $0-25$ & $0-100$ & $0-55.6$ & $0-88.2$ \\
\hline Tanacetum achilleifolium & $n$ & 11 & 7 & 10 & 5 \\
\hline & t-test & & & & \\
\hline & $\mathrm{M} \pm \mathrm{m}$ & $35.0 \pm 9.9$ & & $45.9 \pm 16.6$ & \\
\hline Chorispora tenella & Min-Max & $10-90$ & & $15.4-105.9$ & \\
\hline & $n$ & 7 & & 5 & \\
\hline & $\mathrm{M} \pm \mathrm{m}$ & $11.4 \pm 3.6$ & & $15.9 \pm 4.8$ & \\
\hline Alyssum turkestanicum & Min-Max & $0-25$ & & $0-29.4$ & \\
\hline & $n$ & 7 & & 5 & \\
\hline & $\mathrm{M} \pm \mathrm{m}$ & $24.1 \pm 6.7$ & $29.8 \pm 5.2$ & $20.2 \pm 6.9$ & $33.6 \pm 6.5$ \\
\hline Atrinlex tatarica & Min-Max & $0-65$ & $0-90$ & $0-57.9$ & $0-90$ \\
\hline Alrtplex talartca & $n$ & 11 & 23 & 10 & 19 \\
\hline & t-test & & & & \\
\hline & $\mathrm{M} \pm \mathrm{m}$ & & $38.0 \pm 15.7$ & & $61.0 \pm 24.1$ \\
\hline Salsola australis & Min-Max & & $0-70$ & & $0-116.7$ \\
\hline & $n$ & & 5 & & 4 \\
\hline & $\mathrm{M} \pm \mathrm{m}$ & $28.6 \pm 9.3$ & $53.9 \pm 5.3$ & $29.3 \pm 9.0$ & $65.9 \pm 6.9$ \\
\hline & Min-Max & $0-100$ & $15-100$ & $0-77.8$ & $15-116.7$ \\
\hline Kochia prostrata & $n$ & 11 & 23 & 10 & 19 \\
\hline & t-test & & & & \\
\hline & $\mathrm{M} \pm \mathrm{m}$ & $17.1 \pm 5.7$ & & $28.2 \pm 6.2$ & \\
\hline Descurainia sophia & Min-Max & $0-35$ & & $15.8-46.2$ & \\
\hline & $n$ & 7 & & 5 & \\
\hline
\end{tabular}


closely related plant species have unequal palatability. The baits with extracts from Artemisia austriaca are mostly preferred among Artemisia by voles. In addition, Artemisia stands out for a rather high level of food preference among forbs. Some individuals of voles even preferred baits with Artemisia extracts over the control one. A high level of consumption of the baits with extracts from Kochia prostrata should also be noted. The chemical composition of plants is variable by season. This can be seen from the varying degrees of food selectivity from extracts of spring and autumn plant samples (Artemisia austriaca, A. pauciflora, Tanacetum achilleifolium, Kochia prostrata) by voles. The results show significant differences between preferences of these species demonstrating apparent preference of baits with plant extracts of autumn harvests compared to summer ones.

\section{Discussion}

The voles of genus Microtus are characterized by a high degree of plant-eating and the role of grasses is especially great in their diet (Bashenina, 1977; Batzli, 1985; Polishchuk, 1985; Khashaeva, 1993), which is also supported by our findings. It was previously specified that up to 155 species of forage plants are found in the diet of the social vole (Voronov, 1935b). As for the common vole Microtus arvalis which is close to it, about 450 forage plants were recorded in Europe (Bashenina, 1968, 1977). All this variety of plants is consumed by voles unevenly. The diet diversity is dependent on the species composition and abundance of certain plants in the community. The food selectivity is often highly variable in many voles. The food diversity in one settlement is always much less than the species diversity of forage resources in the range (Kryltsov, 1964; Bashenina, 1977). In addition, the composition of plants in the diet of voles largely depends on the peculiarities of a certain habitat (Okulova et al., 2015).

In our study, 31 out of 34 species (91\%) were registered in the diet of the social vole. This demonstrates the wide trophic plasticity of this rodent. The confinement of the voles to permanent dwelling in their colonies contributes to use of the forage base in the vicinity of this burrow settlement to fullest extent (Khodasheva, 1960; Bukhareva \& Bykov, 2014), it is not surprising therefore that the composition of forage plants of the social vole includes a wide checklist of plant species. Nevertheless, the voles exhibit selectivity in the choice of specific plants, and it may determine the success of the reproduction and survival of vole populations (Krebs, 2013).

The findings show that the basis of the diet of the social vole is vegetative and generative organs of Poa bulbosa. The leading role of Poa bulbosa in the diet was also recorded for this rodent in the steppes of Ukraine (Ivanenko, 1940), in Azerbaijan (Vereshchagin, 1946), and it also forms the basis of forage storage in the close species — the Turkmen vole, Microtus paradoxus (Nurgeldyev, 1956). The little ground squirrel Spermophilus pygmaeus dwelling of the same steppe ecosystems uses Poa bulbosa as main source of the food (Butovsky, 1955). The Libyan jird Meriones libycus also readily consume Poa bulbosa (Andrushko, 1939). The grasses form the basis of nutrition of the common vole (Okulova et al., 2015).

In general, the diet of the social vole consists of grasses, and the species range looks quite similar in different regions. The diversity of the main part of the diet of this rodent includes 2-3 species of grasses in Azerbaijan (Argiropulo, 1935). In the steppes, the food storage of the social vole consists mainly of several types of grasses - Agropyrum sibiricum, Bromus japponicum, Hordeum murinum (Rodionov, 1924). In the clay semideserts of the Volga region, these monocots account for about $50 \%$ of the diet of the social vole (Larionov et al., 2011). The dominance of grasses in the diet and significantly lower consumption of forbs were also observed in the common vole (Luthi et al., 2010).

The reduced consumption of grasses and other plants in the summer can be caused by their drying. Despite the fact that the social vole is adapted to living in dry conditions, these animals cannot eat dry food and die without water after 3-4 days (Rodionov, 1924). Dry food and high body temperature negatively affect the reproduction of these rodents (Vereshchagin, 1946).

Forbs are used by the social vole for nutrition to a much lesser extent than grasses. Other researchers have also noted this fact (Larionov et al., 2011). The reason is the chemical composition of the consumed plants. The secondary metabolites are considered one of the most important components of the qualitative composition of plants that determine the choice of foods by many vertebrates. These compounds primarily affect the initial selection of plants as potential sources of food by an animal, as they have a direct effect on taste and smell determining the flavour of plants (Batzli, 1985; Rosenthal \& Berenbaum, 1991). Forbs contain a wide diversity of these metabolites, while there are practically no such substances in grasses (Scopin, 2003; Abaturov $\&$ Scopin, 2019). This probably explains a large amount of grasses in the diet of the social vole in the steppe and its preference to baits with extracts from these plants.

The voles have a completely different attitude to plants from the group of forbs. Probably, different chemical composition of the plants is the main reason for such selective nutrition. The voles eat a lot of bulbs of Tulipa biebersteiniana from the group of forbs. The baits with extracts of this plant are also preferred in voles in significant numbers.

The plants that are not eaten and rarely eaten by rodents are mostly toxic (Gusynin, 1955). This is illustrated with the small consumption of baits with extracts of Senecio vernalis, Tanacetum achilleifolium, Descurainia sophia. The last two species are recorded as not eaten by the social vole in the steppes of Ukraine (Polishchuk, 1985). Tanacetum achilleifolium is extremely rarely eaten by this vole in the semi-deserts of the Volga region (Larionov et al., 2011). 
In our study, Bassia hyssopifolia, Phlomis pungens, Carduus acanthoides were not found in the diet in nature and also extremely low consumption of Prangos odontalgica, Descurania sophia by the social vole was observed. For example, Bassia hyssopifolia was extremely rarely observed earlier in the diet of the social voles and the tamarisk jird (Meriones tamariscinus) (Pavlov, 1959; Larionov et al., 2011).

The selective consumption of many plants by the social vole is not a condition for its free choice of food items, but often is a compelled phenomenon. The lack of the preferred forages is associated with slow restoration of vegetation after intensive grazing (Kasatkin et al., 1998). The intensive long-term consumption of toxic plant metabolites often leads to damage to internal organs in voles, which may ultimately affect the viability of the population (Jung \& Batzli, 1981; Bergeron et al., 1997). But in general, the voles as plant-eating species have a high degree of resistance to toxic secondary metabolites of plants (Bucyanayandi \& Bergeron, 1990). This explains the high trophic plasticity and adaptability of the social voles to the use of most plants from the nature community as potential food sources.

The variability in the seasonal bait consumption is largely determined by the concentration of toxic substances. We observed high consumption of baits with extracts obtained from autumn plants which can probably be explained by a reduced level of their toxicity to the end of the vegetative season. In our studies, the use of baits with extracts obtained from forbs collected in autumn was always higher than of those from spring samples. Thus, the feeding selectivity allows voles to avoid the consumption of toxic substances and increase the intake of nutrients by means of the consumption of the most high-calorie parts of plants. The absence of statistically significant differences between the consumption of baits with extracts from spring and autumn samples for some plants is associated with high variability at the choice of forage by individual voles. Significant differences in the choice of baits between different individuals in rodents were described long ago (Moshkin \& Shilova, 2008).

The differences between the food selection in nature and bait preferences with plant extracts in the experiment are determined by the fact that in the experiment we analyzed only water extracts which contain mainly toxic substances. But when the voles choose certain plants in nature, they are guided not only by the toxic component of the food plant, but also by its nutritional value, the presence of silica, water and other components.

Some steppe vole species prefer to feed on dicots, but still grasses usually predominate in the diet, as this is the most abundant and affordable food items (Haken \& Batzli, 1996). In our case, the analysis of the reactions of the social voles to bait did not reveal a clear preference for choosing baits with forbs extracts. This suggests complicated trophic relationships in different species of rodents under the influence of a wide range of environmental factors. Understanding the importance of nutritional mechanisms of common species of steppe herbivores will allow us to evaluate their impact on bioproduction processes in these ecosystems.

When we compare the results of the diet selection of voles with the data obtained from the study of feeding of the ungulates in this region (Abaturov et al., 2018, 2019), the first thing that catches your eye is the extremely low rates of SSS index for forage plants in the social vole and high ones for SSS index - in ungulates. If $63 \%$ of the species of the consumed forage plants have SSS index from 0 to 1 in the social vole, only $52.2 \%$ of forage plants have such low index values in the saiga Saiga tatarica and 39\% - in the camel Camelus ferus (Abaturov et al., 2019). On the contrary, about $40 \%$ forage plants in the diets of camel and saiga have SSS index of more than five. For the social vole, we recorded a parameter of more than five for only one species (Artemisia) and only in summer. The phenomenon can probably be explained by the fact that ungulates are more mobile animals and can freely move around the pasture, choosing their preferred plants. Voles, on the contrary, are attached to their colonies and are often have to consume only those plants that are grown near their settlements. Therefore, many plants are not preferred by voles. This is confirmed by the low selectivity indices that we registered for most species of forage plants. Only during the period of active vegetation, when the species richness in the pasture reaches its peak, the voles begin to clearly show high selectivity in the choice of certain plants. When the variety of plants in the pasture drops sharply (in autumnwinter), the vole begins to consume only food remaining in abundance or which is stocked in its burrows.

\section{Conclusion}

The trophic strategy of voles is aimed at the maximum possible consumption of forage plants in the area of their settlements. In conditions of a maximum diversity of vegetation, it manifests high food selection by eating certain species of grasses and Artemisia. In conditions of a limited set of food resources, voles eat only those forages that are available and the feeding selectivity is extremely low. In most cases, voles prefer to consume plants containing the smallest amount of toxic compounds that ensures safe using of forages.

ACKNOWLEDGMENTS. The authors are very grateful to the administration (Director Bataar Ubushaev) and the technical staff of the Chernye Zemli State Biosphere Reserve for the opportunity to fieldwork on the reserve territory. We are also grateful to Grigory Bortsov for technical support in the expedition and to Galina Porchesku and Maria Kushkova for help in translating into English. We are also grateful to the reviewers who undertook a hard task of reviewing our manuscript. This investigation was financially supported by the Russian Foundation for Basic Research (grant No. 18-04-00172). 


\section{References}

Abaturov B.D. 1984. [Mammals as a Component of Ecosystems]. Moscow: Nauka. 286 p. [in Russian].

Abaturov B.D., Dzhapova R.R., Kazmin V.D., Ajusheva E.Ch. \& Dzhapova V.V. 2019. Comparative features of the nutrition of the Przewalski horse Equus przewalskii, the camel Camelus bactrianus, and the saiga Saiga tatarica on an isolated steppe pasture // Biology Bulletin. Vol.46. P.594-607.

Abaturov B.D., Kazmin V.D., Dzhapova R.R., Kolesnikov M.P., Ayusheva E.Ch., Dzhapova V.V., Nokhaeva D.V., Kolesnikov M.P., Minoranskiy V.A. \& Kuznetsov Yu.E. 2018. [Forage resources, nutrition and food supply of free-grazing camels (Camelus bactrianus) in a pasture in the natural steppe zone] // Zoologicheskii Zhurnal. Vol.97. No.3. P.348-361 [in Russian with English summary].

Abaturov B.D. \& Khashaeva M.G. 1995. [Digestion of green vegetable food by rodents with different nutritional types and in relation to the phenophases of plants] // Zoologicheskii Zhurnal. Vol.74. No.4. P.132-142 [in Russian with English summary].

Abaturov B.D. \& Scopin A.E. 2019. [Grasses and forbs in steppe pastures, their toxic properties and comparative role in nutrition of herbivorous mammals] // Zhurnal Obshchei Biologii. Vol.80. No.3. P.226-237 [in Russian with English summary].

Andrushko A.M. 1939. [The Role of Rodents in the Dry Pastures of the Central Asia]. Leningrad: Leningrad State University Press. 153 p. [in Russian with English summary].

Archibald S., Bond W.J., Hoffmann W., Lehmann C., Staver C. \& Stevens N. 2020. Distribution and determinants of savannas // Scogings P.F. \& Sankaran M. (eds.). Savanna Woody Plants and Large Herbivores. Hoboken: John Wiley \& Sons Ltd. P.3-24.

Argiropulo A.I. 1935. [Notes about the summer biology of the social vole in the Transcaucasus (in the conditions of a virgin mixed grass steppe)] // Trudy Azerbaijanskogo Microbiologicheskogo Instituta. Vol.5. No.1. P.217-227 [in Russian with German summary].

Bashenina N.V. 1962. [Ecology of the Common Vole (Microtus arvalis) and Some Features of its Geographical Variability]. Moscow: Moscow State University Press. 308 p. [in Russian].

Bashenina N.V. 1977. [Adaptive Strategies of Microtine Rodents]. Moscow: Nauka. 356 p. [in Russian].

Batzli G.O. 1985. Nutrition // Tamarin R.H. (ed.). Biology of New World Microtus. Special Publication of the American Society of Mammalogists. No.8. P.779-811.

Bergeron J.-M., Jodoin L. \& Jean Y. 1987. Pathology of voles (Microtus pennsylvanicus) fed with plant extracts // Journal of Mammalogy. Vol.68. No.1. P.73-79.

Berishvili I.M. 1968. [Voles of Georgia (Microtus socialis Pall. and Microtus arvalis Pall.) and effective measures to combat them]. Abstract of Dr.Sci. Thesis. Tbilisi: Georgian Agriculture Institute. 53 p. [in Russian].

Bucyanayandi J.-D. \& Bergeron J.-M. 1990. Effects of food quality on feeding patterns of meadow voles (Microtus pennsylanicus) along a community gradient // Journal of Mammalogy. Vol.71. No.3. P.390-396.

Bukreeva O.M. \& Lidzhi-Garyaeva G.V.2018. [Mass migration and death of the social voles (Microtus socialis (Pallas,
1773) in the Northwest Caspian Lowland] // Aridnye Ekosystemy. Vol.24. No.2 (75). P.82-88 [in Russian].

Bukhareva O.A. \& Bykov A.V. 2014. [Spatial and temperature characteristics of social vole (Microtus socialis) burrows in the clay semi-desert of the Trans-Volga Region] // Zoologicheskii Zhurnal. Vol.93. No.12. P.1461-1469 [in Russian].

Butovsky P.M. 1955. [Seasonal changes in the nutrition of the little ground squirrel (Spermophilus pygmaeus) and the nature of its distribution in the Western Kazakhstan]. Abstract of PhD Thesis. Alma-Ata: Institut Zoologii Akademii Nauk Kazakhskoi SSR. 15 p. [in Russian].

Bykov A.V., Kolesnikov A.V., Kulakova N.Yu. \& Shabanova N.P. 2008. Accumulation of moisture and soil erosion in the territory of social vole (Microtus socialis) settlements in the Northern Caspian Lowland // Eurasian Soil Science. Vol.41. No.8. P.902-906.

Bykov A.V., Shabanova N.P. \& Bukhareva O.A. 2011. Distribution and survival of the social vole in a clayey semidesert of the Trans-Volga Region // Biology Bulletin. Vol.38. No.10. P.957-961.

Bykov B.A. 1978. [Geobotany]. Alma-Ata: Nauka. 288 p. [in Russian].

Byrom A.E., Ruscoe W.A., Nkwabi A.K., Metzger K.L., Forrester G.J., Craft M.E., Durant S.M., Makacha S., Bukombe J., Mchetto J., Mduma S.A.R., Reed D.N., Hampson K. \& Sinclair A.R.E. 2015. Small mammal diversity and population dynamics in the Greater Serengeti Ecosystem // Sinclair A.R.E., Metzger K.L., Mduma S.A.R. \& Fryxell J.M. (eds.). Serengeti IV. Sustaining Biodiversity in a Coupled Human-Natural System. Chicago: University of Chicago Press. P.323-357.

Chizhikov O.N. 1954. [Vegetation of Chernye Zemli pastures (Astrakhan Oblast) in connection with the features of their use]. Abstract of PhD Thesis. Moscow: Williams Fodder Research Institute. 20 p. [in Russian].

Doskach A.G. 1979. [Natural Division of the Caspian Semi-Desert]. Moscow: Nauka. 142 p. [in Russian].

Dzhapova R.R., Ayusheva E.Ch., Bembeeva O.G., Dzhapova V.V., Daltaeva Yu.N., Nokhaeva D.V., Nonieva Z.A. \& Babusheva D.B. 2019. [Atlas of the Standard Samples of the Cuticular Surface of Various Plants in the Steppes and Semi-Deserts]. Elista: Kalmyk State University Press. 94 p. [in Russian].

Formozov A.N. \& Kiris I.B. 1937. [Rodent activity on pastures and hayfields. The influence of the social vole (Microtus socialis Pall.) and some other rodents on the vegetation of the Kizlyar district of the Dagestan ASSR] // Uchenye Zapiski Moskovskogo Gosudarstvennogo Universiteta. Zoologiya. Vol.13. P.59-70 [in Russian with English summary].

Gordon I.J. 2006. Restoring the functions of grazed ecosystems // Danell K., Duncan P., Bergstrom R. \& Pastor J. (eds.). Large Herbivore Ecology, Ecosystem Dynamics and Conservation. Cambridge: Cambridge University Press. P.449-467.

Gromov I.M. \& Polyakov I.Ya. 1977. [Fauna of the USSR. Mammals. Vol.3. No.7. Voles (Microtinae)]. Leningrad: Nauka. 504 p. [in Russian].

Gusynin I.A. 1955. [Toxicology of Poisonous Plants]. Moscow: Selkhozizdat. 330 p. [in Russian].

Haken A.E. \& Batzli G.O. 1996. Effects of availability of food and interspecific competition on diets of prairie voles 
(Microtus ochrogaster) // Journal of Mammalogy. Vol.77. No.2. P.315-324.

Ivanenko I.D. 1940. [Microtus socialis Pall. as the principal component of the ecosystem of the Prisivash steppe]// Naukovi Zapiski Khersonskogo Derzhavnogo Pedagogichnogo Instituta N.K. Krupskoi. No.1. P.149-173 [in Ukrainian with English summary].

Ivlev V.S. 1946. The dependence of the food electivity of fishes on the character of its distribution at the bottom of the sea // Zoologicheskii Zhurnal. Vol.25. No.3. P.269-276 [in Russian with English summary].

Jung H.-J.C. \& Batzli G.O. 1981. Nutritional ecology of microtine rodents: effects of plant extracts on the growth of Arctic microtines // Journal of Mammalogy. Vol.62. No.2. P.286-292.

Kasatkin M.V. 2002. [Features of biology and population structure of the social vole (Microtus socialis Pall.)] // Sbornik Nauchnykh Rabot Gosudarstvennogo Biologicheskogo Muzeya K.A. Timiryazeva. Moscow: Erudite-K. P.103-142 [in Russian].

Kasatkin M.V., Isaev S.I. \& Savinetskaya L.E. 1998. [Some features of the ecology of the social vole (Microtus socialis) in the Chernye Zemli (Kalmykia) during increasing numbers] // Zoologicheskii Zhurnal. Vol.77. No.5. P.582-592 [in Russian with English summary].

Kaufman G.A. \& Kaufman D.W. 1997. Ecology of small mammals in prairie landscapes // Knopf F.L. \& Samson F.B. (eds.). Ecology and Conservation of Great Plains Vertebrates. New York: Springer. P.207-243.

Kazmin V.D., Demina O.N., Pozdnyakova M.K., Rozenfeld S.B. \& Abaturov B.D. 2013. [The current state of plant forage resources and feeding selectivity of free horses (Equus caballus) on Steppe Island in Lake Manych-Gudilo] // Zoologicheskii Zhurnal. Vol.92. No.2. P.231-237 [in Russian with English summary].

Khalilaria A. \& Çolak E. 2013. Some ecological aspects of the genus Microtus Schrank, 1798 (Mammalia: Rodentia) in Northwest of Iran // Iranian Journal of Animal Biosystematics. Vol.9. No.2. P.135-146.

Khashaeva M.G. 1993. [Comparative analysis of food consumption and digestion by rodents (for example, Meriones tamariscinus, Mesocricetus raddei, Microtus socialis)]. Abstract of PhD Thesis. Moscow: Institute of Evolutionary Morphology and Animal Ecology. 23 p. [in Russian].

Khodashova K.S. 1960. [The Natural Environment and Fauna of the Clay Semi-deserts of the Volga Region]. Moscow-Leningrad: Izdatelstvo Akademii Nauk SSSR. 140 p. [in Russian]

Kokhiya S.S. 1968. [Social Vole (Microtus socialis Pall.) in Georgia]. Tbilisi: Metzniereba. 135 p. [in Russian].

Krebs Ch. 2013. Population Fluctuations in Rodents. Chicago: University of Chicago Press. 306 p.

Kryltsov A.I. 1964. [Steppe lemmings (Lagurus lagurus) and narrow-headed voles (Lasiopodomys gregalis) in the north of the Kazakhstan] // Trudy Instituta Zashchity Rastenii. Vol.8. P.1-183 [in Russian].

Kryštufek B., Bužan E., Vohralik V., Zareie R. \& Özkan B. 2009. Mitochondrial cytochrome $b$ sequence yields new insight into the speciation of social voles in south-west Asia // Biological Journal of the Linnean Society. Vol.98. P.121-128.
Kryštufek B., Zorenko T. \& Bužan E. 2012. New insights into the taxonomy and phylogeny of social voles inferred from mitochondrial cytochrome $b$ sequences // Mammalian Biology. Vol.77. P.178-182.

Larionov K.O., Bykov A.V., Vyshivkin A.A. \& Shadrina M.B. 2011. The diet composition of the social vole at the beginning stage of colonization of a zonal plain in a clayey semidesert of the Trans-Volga Region // Biology Bulletin. Vol.38. No.10. P.997-1000.

Luthi M., Nentwig W. \& Airoldi J.-P. 2010. Nutritional ecology of Microtus arvalis (Pallas, 1779) in sown wild flower fields and quasi-natural habitats // Revue Suisse de Zoologie. Vol.117. No.4. P.811-828.

Magomedov M.Sh. 2017. [An analysis of rodent feeding in the foothill zone of the Republic of Dagestan: a microhistological cuticular-coprological method] // Zoologicheskii Zhurnal. Vol.96. No.5. P.581-588 [in Russian with English summary].

Moshkin M.P. \& Shilova S.A. 2008. [Morpho-behavioral heterogeneity as the basis of population stability] // Uspekhi Sovremennoi Biologii. Vol.128. No.3. P.307-320 [in Russian with English summary].

Mironov N.P. 1945. [The species composition and ecological distribution of rodents in the Northwestern Caspian Lowland] // Trudy Rostov-na-Donu Protivochumnogo Instituta. Vol.4. P.77-93 [in Russian with English summary].

Naumov N.P. 1948. [Essays on the Comparative Ecology of Microtine Rodents]. Moscow-Leningrad: Izdatelstvo Akademii Nauk USSR. 204 p. [in Russian].

Neronov V.V. 1999. [Natural conditions of the Chernye Zemli Biosphere Reserve] // Zapovednoe Delo. Vol.4. P.87-103 [in Russian].

Nurgeldyev O.N. 1956. [On the geographical distribution and ecology of the social vole (Microtus socialis paradoxus Ogn. et Heptn.) in the Turkmenistan] // Trudy Instituta Biologii Akademii Nauk Turkmenskoi SSR. Vol.4. P.36-44 [in Russian].

Okulova N.M., Mironova T.A., Sapel'nikov S.F., Nikonova O.A., Abaturov B.D. \& Baskevich M.I. 2015. Autumn diets of sibling species Microtus arvalis sensu lato and M. agrestis (Rodentia, Arvicolinae) in the forest-steppe of the Central Chernozem Zone // Russian Journal of Ecology. Vol.46. No.2. P.181-188.

Owen-Smith N. 2005. Adaptive Herbivore Ecology: From Resources to Populations in Variable Environments. Johannesburg: Wits University Press. 392 p.

Pardinas U.F.S., Myers P., Leon-Paniagua L., Ordonez Garza N., Cook J.A., Krystufek B., Haslauer R., Bradley R.D., Shenbrot G.I. \& Patton J.L. 2017. Family Cricetidae // Handbook of the Mammals of the World. Vol.7. Rodents II. Barcelona: Lynx Edicions. P.204-535.

Pavlov A.N. 1959. [On the nutrition of Meriones meridianus and M. tamariscinus in the Northwest Caspian Lowland] // Trudy Rostov-na-Donu Gosudarstvennogo Protivochumnogo Instituta i Stalingradskoi Protivochumnoi Stantsii. Vol.14. P.245-257 [in Russian].

Phillipson J., Sarrasin-Comans M. \& Stomatopoulos C. 1983. Food consumption by Microtus agrestis and the unsuitability of faecal analysis for the determination of preference // Acta Theriologica. Vol.28. P.397-416.

Polishchuk I.K. 1985. [Nutrition of the social vole on the virgin steppe "Askania Nova" and surrounding agroecosystems] // Vestnik Zoologii. No.3. P.70-72 [in Russian]. 
Ponyatovskaya V.M. 1964. [Accounting for the abundance and features of the distribution of species in the natural plant community] // Polevaya Geobotanika. Vol.3. P.209-299 [in Russian].

Rodionov Z.S. 1924. [Biology of the Social Vole and Experiments in Combating it in the Caucasus]. Leningrad: Tipografiya Gutenberga. 191 p. [in Russian].

Rosenthal G.A. \& Berenbaum M.R. (eds.). 1991. Herbivores. Their Interactions with Secondary Plant Metabolites. Vol.1. San Diego: Academic Press. 468 p.

Scholes R.J. \& Walker B.H. 1993. An African Savanna. Cambridge: Cambridge University Press. 306 p.

Scopin A.E. 2000. [The selective preference of plant baits by the common vole (Microtus arvalis)] // Aktualnye Problemy Biologii i Ekologii. Vol.2. Syktyvkar: Institut Biologii Komi Nauchogo Tsentra. P.202-203 [in Russian].

Scopin A.E. 2003. [The Significance of the Components of the Qualitative Composition of Forage Plants for Wild Animals]. Kirov: VNIIOZ. 203 p. [in Russian].

Shilova S.A. \& Kasatkin M.V. 2000. Comparative analysis of the population structure of social vole (Microtus socialis Pall., 1773, Cricetidae, Rodentia) in different areas of its range // Russian Journal of Ecology. Vol.31. No.4. P.262-268.

Shorygin A.A. 1939. Food and food preference of some Gobiidae of the Caspian Sea // Zoologicheskii Zhurnal. Vol.18. No.1. P.27-53 [in Russian with English summary].

Stapp P., Van Horne B. \& Lindquist M.D. 2008. Ecology of mammals of the short-grass steppe // Lauenroth W.K. \& Burke I.C. (eds.). Ecology of the Shortgrass Steppe. A Long-Term Perspective. Oxford: Oxford University Press. P.132-180.

Stewart D.R.M. 1967. Analysis of plant epidermis in faeces: a technique of studying the food preference of grazing herbivores // Journal of Applied Ecology. Vol. 4. P.83-111.
Trofimov I.A. 1995. [Natural pasture lands of the Chernye zemli] // Zonn I.S. \& Neronov V.M. (eds.). Biota i Prirodnaya Sreda Kalmykii. Moscow-Elista: Korkis. P.53-83 [in Russian].

Tsatsenkin I.A., Maksimova V.F. \& Shcherbinovskaya T.N. 1957. [Geobotanical division] // Voronov A.G. (ed.). Trudy Prikaspiskoi Ekspeditsii. Rastitelnost' i Kormovye Resursy Zapadnoi Chasti Prikaspiskoi Nizmennosti i Ergenei. Moscow: Moscow State University Press. P.158-165 [in Russian].

Vereshchagin N.K. 1946. [The main ecological features of the social vole in the semi-desert zone of the Azerbaijan Republic] // Trudy Instituta Zoologii Akademii Nauk Azerbaijanskoi SSR. Vol.11. P.144-182 [in Russian].

Voronov A.G. 1935a. [Some observations of the activity of the social vole (Microtus socialis Pall.) on the foothill pastures of the Dagestan] // Byulleten Moskovskogo Obshchestva Ispytatelei Prirody. Otdel Biologicheskii. Vol.44. No.6. P.314-322 [in Russian with French summary].

Voronov A.G. 1935b. [Some observations of the activity of the social vole (Microtus socialis Pall.) on the foothill pastures of the Dagestan] // Byuleten Moskovskogo Obshchestva Ispytatelei Prirody. Otdel Biologicheskii. Vol.44. No.7/8. P.391-413 [in Russian with French summary].

Zaichenko O.A. 1996. [Herbivores in the Pasture Geosystems of the South Siberia]. Novosibirsk: Nauka. 153 p. [in Russian].

Zlotin R.I. \& Khodashova K.S. 1974. [The Role of Animals in the Biological Cycle of Forest-Steppe Ecosystems]. Moscow: Nauka. 200 p. [in Russian]. 